\title{
The Main Causes and Mechanisms of Increase in Cardiac Troponin Concentrations Other Than Acute Myocardial Infarction (Part I): Physical Exertion, Inflammatory Heart Disease, Pulmonary Embolism, Renal Failure, Sepsis [Corrigendum]
}

Chauin A. Vasc Health Risk Manag. 2021;17:601-617. The author apologizes for this error.

The author has advised there is an error in the author list on page 601. The author name "Aleksey Chauin" should read "Aleksey Chaulin".

\section{Publish your work in this journal}

Vascular Health and Risk Management is an international, peerreviewed journal of therapeutics and risk management, focusing on concise rapid reporting of clinical studies on the processes involved in the maintenance of vascular health; the monitoring, prevention and treatment of vascular disease and its sequelae; and the involvement of metabolic disorders, particularly diabetes. This journal is indexed on PubMed Central and MedLine. The manuscript management system is completely online and includes a very quick and fair peerreview system, which is all easy to use. Visit http://www.dovepress. com/testimonials.php to read real quotes from published authors. 